\title{
State Records and Habitat of Clam Shrimp, Caenestheriella gynecia (Crustacea: Conchostraca), in New York and New Jersey
}

\author{
ROBERT E. SCHMIDT ${ }^{1}$ and ERIK KiviAT
}

Hudsonia Limited, P.O. Box 5000, Annandale, New York 12504 USA

${ }^{1}$ Present address and correspondence to: Bard College at Simon's Rock, 84 Alford Road, Great Barrington, Massachusetts 01230 USA; e-mail: schmidt@ simons-rock.edu

Schmidt, Robert E., and Erik Kiviat. 2007. State records and habitat of Clam Shrimp, Caenestheriella gynecia (Crustacea: Conchostraca), in New York and New Jersey. Canadian Field-Naturalist 121(2): 128-132.

We report new records of the Clam Shrimp, Caenestheriella gynecia Mattox 1950, from three localities in the Hudson Valley of New York and one locality in northeastern New Jersey. All of our specimens were collected in puddles on dirt roads. The New Jersey specimens have meristics that are well within the range of Caenestheriella Daday 1915; however, the eastern New York specimens resemble those reported from Massachusetts with meristics that are closer to Cyzicus Audouin 1837. We hypothesize that $C$. gynecia was established as a parthenogenetic species due to an unlikely dispersal event in the western part of its range and has migrated eastward since the last glacial maximum. Dispersal of this species may occur by wind, in the gut of birds, or stuck to animal feet or fur, or to vehicles. We recommend that $C$. gynecia be treated as rare and vulnerable to extinction throughout its range unless demonstrated otherwise.

Key Words: Clam Shrimp, Caenestheriella gynecia, temporary pond, biogeography, dirt road, New York, New Jersey.

Clam Shrimps are small freshwater bivalvular arthropods in the order Conchostraca. Clam Shrimps inhabit isolated ephemeral pools, temporary ponds, and sometimes lakes; the taxon is found nearly worldwide (Williams 1987). Caenestheriella gynecia Mattox 1950 is a parthenogenetic species with no records of males, although males can be uncommon in related species and may be discovered (see Eder et al. 2000). Until Smith and Gola (2001) reported two populations of this species from western Massachusetts, the known range extended east from Ohio (Smith 2001) to northeastern Pennsylvania. Here we report four localities of $C$. gynecia in the eastern United States, representing range extensions to New York and New Jersey.

\section{Methods}

Specimens were captured from rain puddles and preserved in 50\% isopropanol. Preserved specimens were measured with digital calipers (greatest length in $\mathrm{mm}$ ). Spines on the telson and second antennal segments were counted at $320 \times$ with a stereomicroscope.

\section{Results}

Here we document four collections of Caenestheriella gynecia, representing the first records of this species from New Jersey and New York.

NEW JERSEY: rain puddles on unimproved Paterson Lateral Gas Pipeline road between Empire Avenue and the New Jersey Turnpike, Borough of Carlstadt and Township of South Hackensack, Bergen County, 7402'26"W longitude, 4049'37"N latitude, Hackensack Meadowlands. [Weehawken, New JerseyNew York. 1967, U.S. Geological Survey (USGS) 7.5 minute topographic map sheet], E. Kiviat, 2 September 2001. 6 specimens (Kiviat and MacDonald 2004).
NEW YoRK: rain puddle on abandoned farm road, $3.5 \mathrm{~km}$ south of Rhinebeck, Dutchess County, 7355'15"W longitude, 41 ${ }^{\circ} 53^{\prime} 19^{\prime \prime} \mathrm{N}$ latitude, Town of Rhinebeck, [Kingston East, New York. 1963, photorevised 1980 USGS 7.5 minute topographic map sheet], S. Nyman, 27 May 1994. 1 specimen, $7.6 \mathrm{~mm}$, dried (Site C-3 in Kiviat et al. 1994*).

NEW YoRK: rain puddles on dirt road, ca. $1.4 \mathrm{~km} \mathrm{NNW}$ of East Park, Dutchess County, $73^{\circ} 55^{\prime} 20^{\prime \prime} \mathrm{W}$ longitude, 41 $48^{\circ} 19^{\prime \prime} \mathrm{N}$ latitude, Town of Hyde Park, [Hyde Park, New York. 1963, USGS 7.5 minute topographic map sheet] E. Kiviat \& J. Bridges, 26 June 2002. 5 specimens.

NEW YoRK: rain puddles on ATV trail, ca. $3.4 \mathrm{~km} \mathrm{NNE} \mathrm{of}$ Saugerties, Greene County, $73^{\circ} 55^{\prime} 58^{\prime \prime} \mathrm{W}$ longitude, $42^{\circ} 06^{\prime} 33^{\prime \prime} \mathrm{N}$ latitude, Bristol Beach State Park [Saugerties, New York. 1963, USGS 7.5 minute topographic map sheet], E. Kiviat, 25 July 2007. 1 specimen.

Clam Shrimp habitats (Figure 1) at the New York and New Jersey localities were all rain puddles on dirt roads. Clam Shrimp were observed swimming slowly on the underside of the surface film in New Jersey, and swimming in the water column and along the bottom in New York. The puddles were ca. $1.5-30 \mathrm{~m}^{2}$ and ca. $5-15 \mathrm{~cm}$ deep at the dates of collection. The rain puddles essentially lacked vascular plants. We have visited the puddles at the New Jersey locality several times at different seasons 2002-2007; some of the puddles maintained their depths even during dry periods, but did dry during the summer 2005 drought. The New Jersey puddles were consistently very turbid and Clam Shrimp were not visible below the surface; the Hyde Park pools were clear enough to see Clam Shrimp swimming along the bottom. The roads at the New Jersey and Saugerties, New York localities are regularly used by all-terrain 


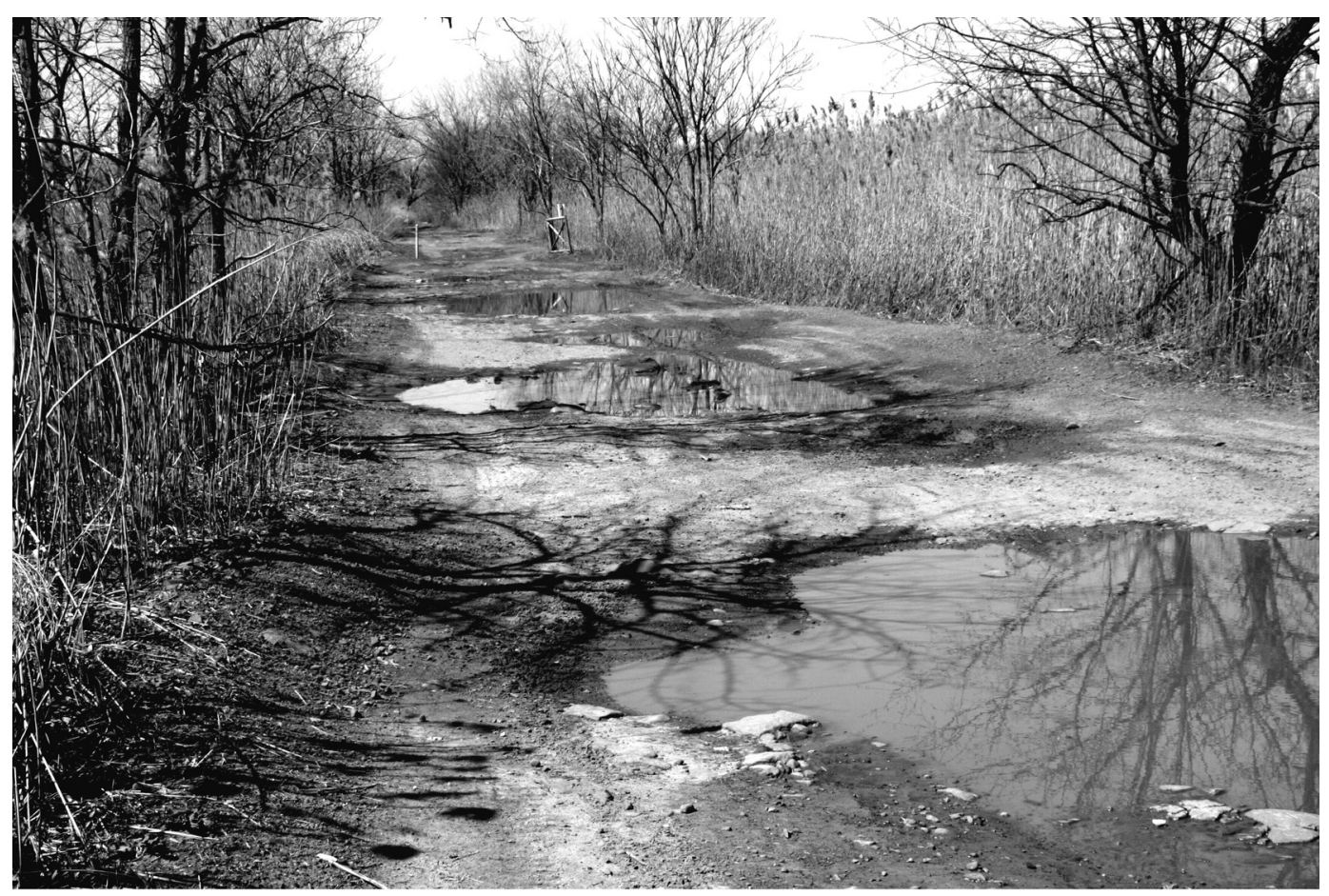

FIGURE 1. Habitat of Caenestheriella gynecia in New Jersey. Photograph by Erik Kiviat.

vehicles (including "four-wheelers" and motorcycles), and road vehicles (pickup trucks and sport-utility vehicles) were observed using the road at the Hyde Park locality. The puddles at the Bristol Beach State Park site were created and maintained by all-terrain vehicle use. We believe the puddle habitats at these four sites were created and maintained by wheeled vehicles; the puddles at the Rhinebeck locality appeared less recently disturbed and may have been created by farm vehicles. The dirt road at the Hyde Park locality was bordered by hardwood forest and woodland pools. The dirt road at the Rhinebeck locality was fringed by tall shrubs and small trees in the midst of a wet meadow and old field. In New Jersey, the dirt road was fringed by Common Reed (Phragmites australis), tall shrubs, and small trees, and was raised ca. $1.5 \mathrm{~m}$ above the level of extensive, formerly tidal, marsh now dominated by common reed. The ATV trail at the Bristol Beach site was bordered by second-growth hardwood forest.

The Hyde Park and Rhinebeck roads appear to comprise in situ soil materials which are mapped as Nassau-Cardigan complex (Lithic and Typic Dystrochrepts) and Sun silt loam on glacial till, and Hudson-Vergennes soil (Glossaquic Hapludalf) on glaciolacustrine silty clay, respectively (Faber 2002*). The Saugerties site has soils mapped as Hudson silt loam, a Glassaquic Hapludalf and Madalin silty clay loam, a Mollic Ochraqualf according to Tormes (1979*).

The $\mathrm{pH}$ of these soils varies from strongly or very strongly acidic at the surface to moderately akaline in the substratum (Faber 2002*). Wetlands adjoining the New Jersey site were mapped as Sulfhemists and Sulfaquents (Goodman 1995*); however, the dirt road appears to have been constructed from imported material with a light reddish color that may have originated from nearby red Triassic shale and sandstone (Schuberth 1968). We have not found Clam Shrimp in wetlands adjoining the dirt road habitats.

Smith and Gola (2001) discussed generic placement of this species and showed that the meristics on their Massachusetts specimens were not typical of Caenestheriella but were intermediate or closer to species of Cyzicus Andouin 1837. The most significant difference in the genera is the shape of the male rostrum which cannot be determined in our specimens. There are differences in the number of spines on the telson, but the counts on the Massachusetts specimens overlapped the genera and Smith and Gola (2001) questioned whether the two genera were distinct. The size and meristics of our New Jersey specimens (Table 1) fall clearly within Caenestheriella Daday 1915 (all specimens contained eggs) as did the single specimen from Saugerties (west of the Hudson River). Our New York specimens from east of the Hudson River, however, are similar to those in western Massachusetts. It is possible that the eastern New York and Massachusetts populations are Cyzicus.

\section{Discussion}

Caenestheriella gynecia inhabits temporary freshwater pools and was considered a "warm water" species 
TABLE 1. Size and meristics of Caenestheriella gynecia (Clam Shrimp) specimens from New Jersey and New York.

\begin{tabular}{lcccc}
\hline \hline State & $\begin{array}{c}\text { Number } \\
\text { of specimens }\end{array}$ & $\begin{array}{c}\text { Mean } \\
\text { (range) size, mm }\end{array}$ & $\begin{array}{c}\text { Number of } \\
\text { telson spines }\end{array}$ & $\begin{array}{c}\text { Number of } \\
\text { segments, 2nd antennae }\end{array}$ \\
\hline New Jersey & 6 & $4.75(4.2-5.2)$ & $18-22$ & $15-19$ \\
New York & 5 & $9.10(8.6-10.2)$ & $27-32$ & $15-20$ \\
\hline \hline
\end{tabular}

by Weeks and Marcus (1997). This is typical habitat for a suite of clam shrimp and relatives (Anostraca, Notostraca) and for certain distantly related species of Cladocera and Ostracoda (Williams 1987). The diversity of aquatic animals in a given pool is low, however, probably due to the habitat's inherent instability and simplicity. Caenestheriella gynecia appears to be different from its close and distant relatives in that it is known mostly from rain puddles on dirt roads; the type locality (Mattox 1950), a second location in Ohio (Emberton 1980), one of the populations in Massachusetts (Smith and Gola 2001), and this paper. Although the puddles in which we found $C$. gynecia are more-orless permanent, their small size (and high turbidity in the case of the New Jersey pools) may exclude some aquatic predators much as does impermanence.

Wiggins et al. (1980) and Williams (1985) characterized the resident biota of ephemeral aquatic habitats as having high fecundity, short life spans, and rapid maturation. Additionally Clam Shrimp produce "resting eggs" (Hann 1996*) which can tolerate heat, cold, and dessication and may require freezing or drying to hatch (Mattox and Velardo 1950; Belk and Belk 1975).

Hann $(1996 *)$ observed that the small scale distribution of Caenestheriella setosa was patchy, with some puddles inhabited while nearby puddles were empty. This suggests that, despite the Clam Shrimp's investment in large numbers of resting eggs, egg survival is low, even short-distance dispersal is difficult, or local extinction (in a pool) is frequent. Boileau and Taylor (1994) showed that related organisms had poor dispersal over even very short distances and calculated that there were 0.6-4.5 dispersers per generation in small pools in South Carolina. We presume that dispersal of Clam Shrimp is primarily in the resting egg stage and we can envision several modes of dispersal of these eggs.

Eggs of $C$. gynecia from desiccated puddles could be blown along with soil particles from one puddle or locality to another. Animals passing through puddles, especially species that spend time in muddy habitats, could pick up eggs in mud adhering to their feet, shells, or fur. Potential vectors of dispersal include Raccoons (Procyon lotor, see Maguire 1963), Mallards (Anas platyrhynchos), Snapping Turtles (Chelydra serpenti$n a)$, and humans. More recently, human traffic in the form of wheeled or tracked vehicles could act as a dispersal agent.

Although our few specimens of $C$. gynecia do little to establish a pattern that would resolve the taxonomic question posed by Smith and Gola (2001), there is a geographic pattern that deserves discussion. All known localities for this species are within the maximum ex- tent of the Wisconsinan glaciation (Figure 2) except one location in central Ohio (Emberton 1980). It is, of course, possible that not all populations of this species have been documented (especially since we are here reporting several) and that there may be populations to the south of the known distribution. This is important because robust biogeographic hypotheses do require accurate knowledge of an animal's distribution. Although this species is rare, there are a number of researchers actively working with Clam Shrimp in the midwestern and southern United States and there have been no other reports of this species.

This distribution suggests the following hypotheses. Caenestheriella gynecia is derived from a sexually reproducing species, probably $C$. setosa, whose range is closest to $C$. gynecia. Dispersal into the glaciated area occurred in the Ohio Valley and was an unlikely event given the dispersal mechanisms of the species. Unlikely dispersal would favor establishment of a parthenogenetic individual over at least two sexually reproducing ones. This scenario suggests that $C$. gynecia is relatively young, less than 12500 years old (the approximate age of the last glacial retreat).

Dispersal eastward from the Ohio Valley would be equally unlikely except that seasonally muddy dirt roads were created soon after European colonization of the northeastern states. Caenestheriella gynecia could have spread as eggs in mud splattered on wagons or horses' hoofs and its distribution would follow traffic flow. Recently, many of these colonial roads have been paved, leaving $C$. gynecia to persist in the remaining dirt road habitats, including farm roads, logging roads, and service roads for powerlines and pipelines.

The above scenario could be corroborated by phylogenetic and genetic analyses. The closest living relative of $C$. gynecia should be geographically very close to $C$. gynecia but we are unaware of any phylogenetic analyses of this genus. Additionally, the genetic variation in $C$. gynecia should be minimal because it is parthenogenetic, has been derived from a very small founder population, and is geologically young.

Caenestheriella gynecia or its ancestors could have evolved in association with American Bison (Bison bison), living in "buffalo wallows" and dispersing in mud caked on Bison fur or hoofs. Butler (1995) noted buffalo wallows somewhat larger than the puddles where we collected $C$. gynecia and alluded to observations of mud stuck to fur. Dispersal of resting stages in the guts of birds is also possible for C. gynecia. Proctor et al. (1967) found that Artemia eggs and the eggs and adults of Ostracoda could remain viable after passing through the gut of Killdeer (Charadrius vociferus). 


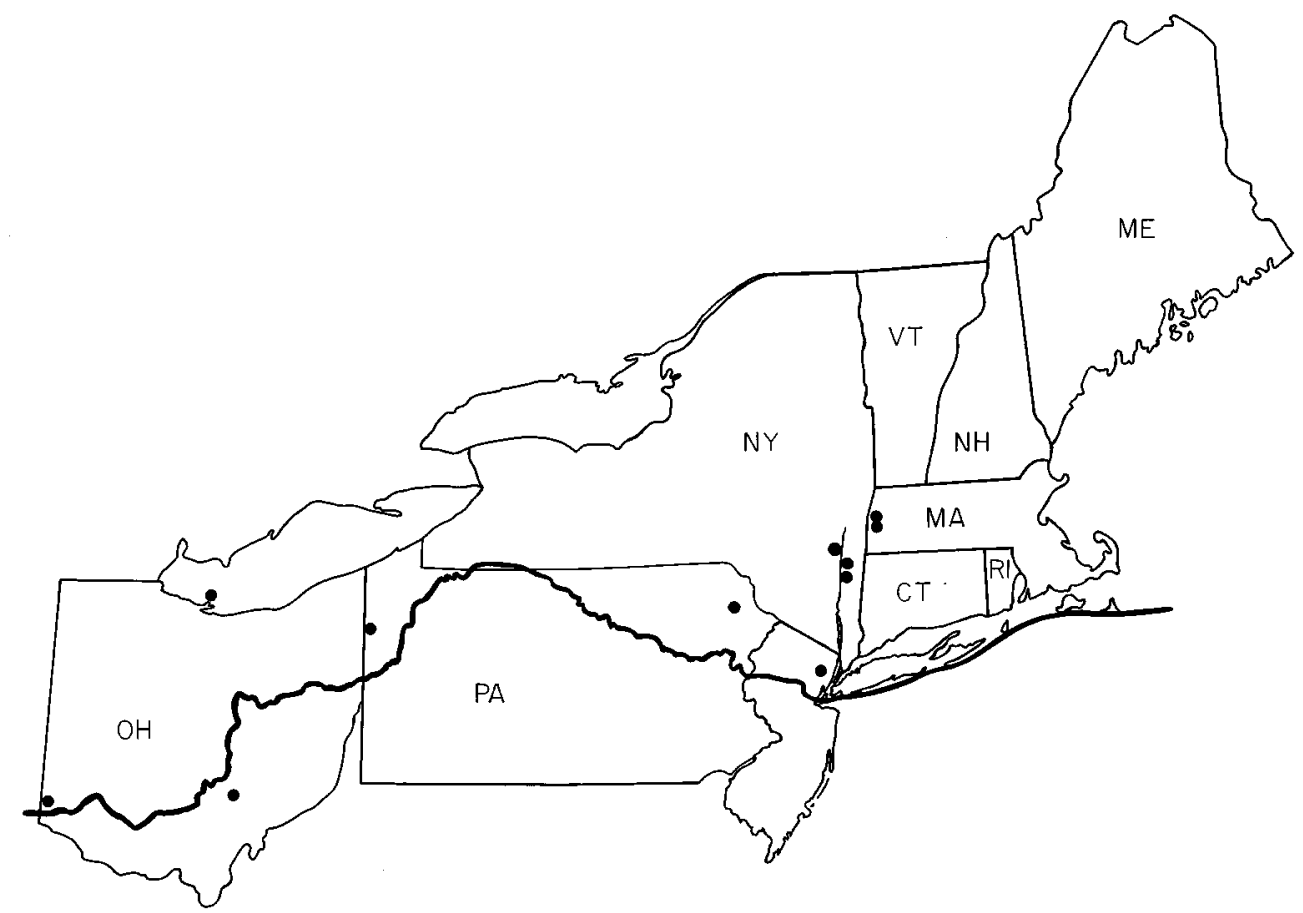

FIGURE 2. Map of the eastern United States showing collection localities of Caenestheriella gynecia in relation to the southern extent of the most recent glaciation.

Long distance $(1400 \mathrm{~km})$ dispersal of Caenestheriella belfragei was presumed due to eggs being carried on or in waterfowl (Donald 1989). Proctor (1954) showed that viable eggs of some phyllopods could pass through the gut of ducks. If $C$. gynecia had been carried to the glaciated areas by waterfowl, its close relatives could be anywhere along the waterfowl flyways.

Two of the New York and the New Jersey Clam Shrimp localities are privately owned. The Hyde Park road is part of a residential subdivision and reportedly has been excavated for installation of a water pipeline. The New Jersey road is subject to gas pipeline maintenance activities and adjoins The Richard P. Kane Natural Area, possibly subject to habitat restoration. Because field surveys have not been conducted to determine the distribution of, and degree of threat to, C. gynecia populations in the northeastern states, we recommend this species be treated as rare and vulnerable to extinction unless demonstrated otherwise. Only 11 localities (Figure 2) have been reported for C. gynecia, including our localities, although a recent Ohio survey listed just one site (Weeks and Marcus 1997). If this Clam Shrimp were reviewed by state Natural Heritage Programs in New York and New Jersey it would be ranked as G2, S1 assuming all the reported sites are extant. We recommend that dirt roads one year or more old with long-lasting rain puddles $>1 \mathrm{~m}^{2}$ and $>5 \mathrm{~cm}$ deep be checked for Clam Shrimp during JuneSeptember as part of land management or environmen- tal review processes. Clam Shrimp may sometimes be observed swimming in the pools and may be captured by sweeping a fine-mesh dipnet through the pools.

Research, conservation, management, and restoration of biodiversity are most often done in wildlands and natural areas. Yet urban, industrial, and other altered landscapes are expanding rapidly in North America. Certain rare or declining native species survive or even thrive in human-altered landscapes. Examples of rare species occupying human-disturbed soils are: Knieskern's Beaked Rush (Rhynchospora knieskernii) in a tire rut and on a waste dump in the New Jersey Pine Barrens (Schuyler 1999) and larvae of the Regal Fritillary (Speyeria idalia) overwintering in soils disturbed by tanks in Pennsylvania (Rosenzweig 2003). These ecological distributions can be the result of human activities creating a surrogate habitat type or physical-chemical environment not otherwise available, an abundance of food, reduced predation or competition, or persistence during landscape change (see, e.g., Adams 1994). It can be said that "Biodiversity is where you find it." Therefore conservation biologists and environmental planners need to pay more attention to organisms such as Caenestheriella gynecia and the artificial or altered habitats that support them. Altered or artificial habitats of types known to support rare organisms should be surveyed for those species routinely, much as natural and semi-natural habitats are surveyed for rare species. Those sites discovered to support a rare 
species, such as the Clam Shrimp sites reported here, should be considered for conservation management. In the case of Caenestheriella gynecia, management may need to include a degree of controlled motor vehicle activity or its equivalent to maintain the puddle habitat and potentially disperse Clam Shrimp among puddles. We recommend that this species be considered rare and vulnerable to extinction throughout its range unless demonstrated otherwise.

\section{Acknowledgments}

Joseph T. Bridges and Stephen Nyman collaborated in the field. Kathleen Schmidt drew Figure 2. Clam Shrimp were collected and the manuscript prepared during studies funded by the Geraldine R. Dodge Foundation, H2O Fund (Highlands to Ocean Fund), Geoffrey C. Hughes Foundation, Mary Jean and Frank P. Smeal Foundation, Hackensack Meadowlands Partnership, Matthew D. Rudikoff Associates, and U.S. Environmental Protection Agency. This paper has not been reviewed by the funders; opinions herein are solely those of the authors. This is Bard College Field Station - Hudsonia Contribution 87.

Documents Cited [marked $*$ in text]

Faber, M. 2002. Soil survey of Dutchess County, New York. U.S. Department of Agriculture, Natural Resources Conservation Service. 356 pages + folded maps in case.

Goodman, S. D. 1995. Soil survey of Bergen County, New Jersey. U.S. Department of Agriculture, Soil Conservation Service. 142 pages + folded maps in case.

Hann, B. J. 1996. Ecology of aquatic invertebrates in temporary habitats: Caenestheriella setosa (Conchostraca, Crustacea) in Delta Marsh, MB, Canada. University Field Station (Delta Marsh) Annual Report 31: 43-46.

Kiviat, E., P. M. Groffman, G. Stevens, S. Nyman, and G. C. Hanson. 1994. Reference wetlands in eastern New York. Report to the U.S. Environmental Protection Agency. Hudsonia Ltd., Annandale, New York. 94 pages.

Tormes, L. A. 1979. Soil survey of Ulster County, New York. U.S. Department of Agriculture, Soil Conservation Service. 273 pages plus maps.

\section{Literature Cited}

Adams, L. W. 1994. Urban wildlife habitats; a landscape perspective. University of Minnesota Press, Minneapolis, Minnesota. 187 pages.

Audouin, V. 1837. Séance du 1 fevrier 1837. Annals of the Society of Entomology, France. 6: 9-11.

Belk, D., and M. S. Belk. 1975. Hatching temperatures and new distributional records for Caenestheriella setosa (Crustacea, Conchostraca). Southwestern Naturalist 20: 409-411.

Boileau, M. G., and B. E. Taylor. 1994. Chance events, habitat age, and the genetic structure of pond populations. Archiv für Hydrobiologie 132: 191-202.

Butler, D. R. 1995. Zoogeomorphology; animals as geomorphic agents. Cambridge University Press, New York, New York. 231 pages.
Daday, E. 1915. Monographie systémitique des phyllopodes conchostraces. Annales des Sciences Naturelles, Series 9. 20: 39-330.

Donald, D. B. 1989. First Canadian record for the clam shrimp Caenestheriella belfragei (Crustacea: Conchostraca). Canadian Field-Naturalist 103: 593-594.

Eder, E., S. Richter, R. Gottwald, and W. Hodl. 2000. First record of Limnadia lenticularis males in Europe (Branchiopoda: Conchostraca). Journal of Crustacean Biology 20: 657-662.

Emberton, K. C., Jr. 1980. Ecology of a fall population of the clam shrimp Caenestheriella gynecia Mattox (Crustacea: Conchostraca). Ohio Journal of Science 80: 156-159.

Kiviat, E., and K. MacDonald. 2004. Biodiversity patterns and conservation in the Hackensack Meadowlands, New Jersey. Urban Habitats 2: 28-61.

Maguire, B., Jr. 1963. The passive dispersal of small aquatic organisms and their colonization of isolated bodies of water. Ecological Monographs 33: 161-185.

Mattox, N. T. 1950. Notes on the life history and description of a new species of conchostracan phyllopod, Caenestheriella gynecia. Transactions of the American Microscopical Society 69: 50-53.

Mattox, N. T., and J. T. Velardo. 1950. Effect of temperature on the development of the eggs of a conchostracan phyllopod, Caenestheriella gynecia. Ecology 31: 497-506.

Proctor, V. W. 1954. Viability of crustacean eggs recovered from ducks. Ecology 45: 655-658.

Proctor, V. W., C. R. Malone, and V. L. DeVlaming. 1967. Dispersal of aquatic organisms: viability of disseminules recovered from the intestinal tract of captive killdeer. Ecology 48: 672-676.

Rosenzweig, M. L. 2003. Win-win ecology; how the earth's species can survive in the midst of human enterprise. Oxford University Press, Oxford, UK. 211 pages.

Schuberth, C. J. 1968. The geology of New York City and environs. Natural History Press, Garden City, New York. 304 pages.

Schuyler, A. E. 1999. Defining nature and protecting rare plants. Ecological Restoration 17: 5-7.

Smith, D. G. 2001. Pennak's freshwater invertebrates of the United States. John Wiley \& Sons, Inc., New York, New York. 621 pages.

Smith, D. G., and A. A. Gola. 2001. The discovery of Caenestheriella gynecia Mattox 1950 (Branchiopoda, Cyzicidae) in New England, with ecological and systematic notes. Northeastern Naturalist 8: 443-454.

Weeks, S. C., and V. Marcus. 1997. A survey of the branchiopod crustaceans of Ohio. Ohio Journal of Science 97: 86-89.

Wiggins, G. B., R. J. Mackay, and L. M. Smith. 1980. Evolutionary and ecological strategies of animals in annual temporary pools. Archives of Hydrobiology, Supplement 58: 97-206.

Williams, D. D. 1987. The ecology of temporary waters. Croom Helm, London, UK and Timber Press, Portland, Oregon. 205 pages.

Williams, W. D. 1985. Biotic adaptations in temporary lentic waters, with special reference to those in arid or semi-arid regions. Hydrobiologia 125: 85-110.

Received 30 January 2006

Accepted 1 May 2008 